\title{
Perkembangan Pendidikan Matematika Realistik INDONESIA (PMRI) DI LPTK BANDUNG RAYA
}

\author{
The DEVELOPMENT OF PENDIDIKAN MATEMATIKa REALISTIK INDONESIA \\ (PMRI) LPTK IN BANDUNG RAYA
}

\author{
Yuniawatika $^{1}$, Devi Nurul Yuspriyati ${ }^{2}$, Ibrahim Sani ${ }^{3}$ and Febriyanti ${ }^{4}$ \\ ${ }^{2}$ Pendidikan Matematika, STKIP Siliwangi Bandung \\ Bandung, Jawa Barat, Indonesia \\ devi_yuspriyati@yahoo.co.id \\ ${ }^{4}$ Pendidikan Matematika, STKIP Siliwangi Bandung \\ Bandung, Jawa Barat, Indonesia \\ febriyantifebriiy@gmail.com
}

\begin{abstract}
Abstrak
Matematika sangat penting untuk menumbuhkembangkan kemampuan berpikir siswa serta menanamkan pendidikan karakter pada diri siswa sehingga dengan kemampuan itu diharapkan peserta didik mampu bertahan hidup dalam keadaan yang tidak pasti dan kompetitif. Namun sampai saat ini sebagian besar siswa tidak menyukai dan bahkan benci dengan matematika karena mereka merasa matematika adalah sesuatu yang membosankan dan menakutkan. terdapat bukti dengan masalah umum matematika seperti rendahnya rata-rata NEM nasional, rendahnya daya saing di ajang internasional serta rendahnya minat belajar matematika. Banyak upaya-upaya yang telah dilakukan oleh pakar pendidikan matematika di Indonesia bahkan di negara-negara maju pun melakukan banyak inovasi-inovasi pendidikan khususnya pada matematika. Indonesia sendiri tengah dipopulerkan Pembelajaran Matematika Realistik Indonesia atau disingkat PMRI. Metode yang digunakan dalam penelitian ini adalah metode penelitian kualitatif yang akan menghasilkan data deskriptif berupa kata-kata tertulis atau lisan dari subjek yang diamati. Teknik pengumpulan data yang digunakan adalah dengan menggunakan metode observasi, metode angket, metode wawancara, dan dokumentasi. Hasil penelitian ini bahwa Perkembangan PMRI di Jawa Barat khususnya Bandung Barat belum berkembang maksimal sesuai yang diharapkan pada saat pertama kali PMRI dikenalkan di Indonesia. Hal ini dapat dilihat hanya beberapa yang menerapkan PMRI itu sendiri di sekolah. Pada saat sekarang ini LPTK-LPTK sudah mulai jarang mengadakan pelatihan/workshop, seminar dan juga penelitian yang bertemakan PMRI. Kemudian ditunjang juga bahwa kurang adanya dukungan dari pemerintah mengenai PMRI. Sehingga, PMRI dalam perkembangannya belum menyebar secara menyeluruh di Bandung Raya.
\end{abstract}

Kata Kunci: Pendidikan Matematika Realistik Indonesia (PMRI), LPTK.

\begin{abstract}
Math is very important to develop students' thinking skills and instill character education on students with abilities so that learners are expected to survive in an uncertain and competitive . However, to date most of the students do not like and even hate math because math is something they feel boring and intimidating. there is evidence of the general mathematical problems such as low national average NEM, low competitiveness in the international arena as well as the lack of interest in learning mathematics. Many efforts have been made by experts of mathematics education in Indonesia, even in developed countries also do a lot of innovations in education, especially in mathematics. Indonesia is in the midst popularized Realistic Mathematics Education
\end{abstract}


Indonesia or abbreviated PMRI. The method used in this study is a qualitative research method that will generate descriptive data in the form of words written or spoken of the subject being observed. Data collection techniques used is to use the method of observation, questionnaire, interview, and documentation. The results of this study that PMRI Developments in West Bandung West Java has not been fully developed as expected when first introduced in Indonesia PMRI. It can be seen that only a few PMRI apply themselves in school. At this present time LPTKS - LPTK already begun rarely held pelatiha / workshops, seminars and study also the theme PMRI. Then also supported that the lack of support from the government regarding PMRI. Thus, PMRI in its development as a whole has not spread in Bandung Raya.

Keyword: Pendidikan Matematika Realistik Indonesia (PMRI), LPTK.

\section{Pendahuluan}

Matematika merupakan ilmu yang sangat penting untuk dipelajari mulai dari jenjang pendidikan dasar hingga pendidikan lanjutan. Hal ini sejalan dengan Peraturan Mentri No. 22 Tahun 2006, mata pelajaran Matematika perlu diberikan kepada semua peserta didik mulai dari sekolah dasar untuk membekali peserta didik dengan kemampuan berpikir logis, analitis, sistematis, kritis, dan kreatif, serta kemampuan bekerjasama.

Namun sampai saat ini sebagian besar siswa tidak menyukai dan bahkan benci dengan matematika karena mereka merasa matematika adalah sesuatu yang membosankan dan menakutkan. Seperti yang dikemukakan Ruseffendi, "Matematika (ilmu pasti) bagi anak-anak pada umumnya merupakan mata pelajaran yang tidak disenangi, kalau bukan pelajaran yang paling dibenci." [1] Selain itu, terdapat bukti dengan masalah umum matematika seperti rendahnya rata-rata NEM nasional, rendahnya daya saing di ajang internasional serta rendahnya minat belajar matematika. Rendahnya daya saing di ajang internasional terbukti dengan adanya hasil penelitian yang dilakukan tim Program of International Student Assessment (PISA) pada tahun 2009:
Indonesia menempati urutan 61 dari 65 negara dalam matematika. Soal-soal yang diberikan PISA bukan sekedar soal-soal untuk mengetahui kemampuan siswa dalam menyelesaikan soal-soal atau soalsoal yang mekanistik tetapi soal-soal yang dimaksudkan untuk mengidentifikasi dan memahami serta menggunakan dasar-dasar matematika yang diperlukan seseorang dalam menghadapi kehidupan sehari-hari.

Pada umumnya pendekatan pengajaran matematika di Indonesia masih menggunakan pendekatan konvensional atau mekanistik yang menekankan proses 'drill and practice', prosedural serta menggunakan rumus dan algoritma sehingga siswa dilatih mengerjakan soal seperti mesin yang sudah terprogram. Akibatnya bila siswa diberikan soal yang berbeda dengan soal latihan maka siswa kebingungan untuk mengerjakannya hal tersebut akibat tidak terbiasanya memecahkan masalah. Padahal seharusnya menurut Sumarmo pembelajaran matematika mengacu pada prinsip siswa belajar aktif, dan "learning how to learn" yang rinciannya termuat dalam empat pilar pendidikan yaitu: (1) learning to know, (2) learning to do, (3) learning to be, dan (4) learning to live together [2]. Kurikulum matematika sekolah memuat rincian topik, 
kemampuan dasar matematika, dan sikap yang diharapkan dimiliki siswa pada tiap jenjang sekolah.

Banyak upaya-upaya yang telah dilakukan oleh pakar pendidikan matematika di Indonesia bahkan di negaranegara maju pun melakukan banyak inovasi-inovasi pendidikan khusunya pada matematika. Misalnya Indonesia sendiri tengah dipopulerkan Pembelajaran Matematika Realistik Indonesia atau disingkat PMRI. Pendidikan Matematika Realistik yang disingkat PMR merupakan terjemahan Realistic Mathematics Education yang disingkat RME.

Berdasarkan pernyataan diatas, maka rumusan masalah dalam penelitian ini adalah

1. Sampai seberapa jauh PMRI diterapkan di Bandung Raya?

2. Apakah yang telah dilakukan oleh masing-masing LPTK untuk mengembangkan dan menyebarluaskan PMRI?

3. Kesukaran-kesukaran apa yang telah dialami oleh LPTK masing-masing untuk mengembangkan dan menyebarluaskan PMRI?

4. Bantuan-bantuan apa yang diperlukan agar PMRI berkembang dan dikenal oleh masyarakat luas khususnya di sekolah?

Dengan tujuan penelitian ini adalah

1. Lebih memahami apa yang disebut PMRI (Pendidikan Matematika Realistik di Indonesia)

2. Untuk mengetahui sejauh mana penerapan PMRI di Bandung Raya telah dilakukan oleh para peserta workshopnya.
3. Untuk mendeskripsikan bagaimana kesulitan-kesulitan yang telah dialami oleh LPTK untuk mengembangkan dan menyebarluaskan PMRI.

Berusaha membentuk Tim PMRI di STKIP Siliwangi.

Pendidikan Matematika Realistik Indonesia (PMRI) merupakan adaptasi dari Realistic Mathematics Education $(R M E), \quad$ teori pembelajaran yang dikembangkan di Belanda sejak tahun 1970-an oleh Hans Freudenthal. Sejarahnya PMRI dimulai dari usaha mereformasi pendidikan matematika yang dilakukan oleh Tim PMRI (dimotori oleh Prof. RK Sembiring dkk) sudah dilaksanakan secara resmi mulai tahun 1998, pada saat tim memutuskan untuk mengirim sejumlah dosen pendidikan matematika dari beberapa LPTK di Indonesia untuk mengambil program S3 dalam bidang pendidikan matematika di Belanda.

Selanjutnya ujicoba awal PMRI sudah dimulai sejak akhir 2001 di delapan sekolah dasar dan empat madrasah ibtidaiyah. Kemudian, PMRI mulai diterapkan secara serentak mulai kelas satu di Surabaya, Bandung dan Yogyakarta. Setelah berjalan delapan tahun, pada tahun 2009 terdapat 18 LPTK yang terlibat, yaitu 4 LPTK pertama ditambah UNJ (Jakarta), FKIP Unlam Banjarmasin, FKIP Unsri Palembang, FKIP Unsyiah (Banda Aceh), UNP (Padang), Unimed (Medan), UM (Malang), dan UNNES (Semarang), UM (Universitas Negeri Malang), dan Undiksa Singaraja, Bali, UNM Makassar, UIN Jakarta, Patimura Ambon, Unri Pekan Baru, dan Unima Manado. Selain itu juga 
ada Unismuh, Uiversitas Muhamadiyah Purwokerto dan STKIP PGRI Jombang.

\section{A. Pendekatan PMRI}

PMRI atau RME adalah teori pembelajaran yang bertitik tolak dari halhal yang riil atau pernah dialami siswa, menekankan keterampilan proses, berdiskusi dan berkolaborasi, berargumentasi dengan teman sekelas sehingga mereka dapat menemukan sendiri (student centered) sebagai kebalikan dari pembelajaran berpusat pada guru (teacher centered) dan pada akhirnya menggunakan matematika itu untuk menyelesaikan masalah baik secara individu maupun kelompok dalam kehidupan mereka sehari-hari.

Pada pendekatan PMRI, guru berperan tidak lebih dari seorang fasilitator atau pembimbing, moderator dan evaluator. Hadi menyebutkan bahwa diantara peran guru dalam PMRI adalah sebagai berikut: [3]

1. Guru hanya sebagai fasilitator belajar;

2. Guru harus mampu membangun pengajaran yang interaktif;

3. Guru harus memberikan kesempatan kepada siswa untuk secara aktif menyumbang pada proses belajar dirinya, dan secara aktif membantu siswa dalam menafsirkan persoalan riil; dan

4. Guru tidak terpancang pada materi yang termaktub dalam kurikulum, melainkan aktif mengaitkan kurikulum dengan dunia riil, baik fisik maupun sosial.

Dengan penerapan PMRI di Indonesia diharapkan prestasi akademik siswa meningkat, baik dalam mata pelajaran matematika maupun mata pelajaran lainnya. Sejalan dengan paradigma baru pendidikan sebagaimana yang dikemukakan Zamroni, pada aspek perilaku diharapkan siswa mempunyai ciri-ciri: [3]

1. Di kelas mereka aktif dalam diskusi, mengajukan pertanyaan dan gagasan, serta aktif dalam mencari bahan-bahan pelajaran yang mendukung apa yang tengah dipelajari;

2. Mampu bekerja sama dengan membuat kelompok-kelompok belajar;

3. Bersifat demokratis, yakni berani menyampaikan gagasan, mempertahankan gagasan dan sekaligus berani pula menererima gagasan orang lain;

4. Memiliki kepercayaan diri yang tinggi.

\section{B. Hakekat PMRI}

RME banyak diwarnai oleh pendapat Profesor Hans Freudenthal (1905 - 1990), seorang penulis, pendidik, dan matematikawan berkebangsaan Jerman/Belanda. Freudenthal berkeyakinan bahwa siswa tidak boleh dipandang sebagai penerima pasif matematika yang sudah jadi (passive receiver of ready-made mathematics). Dua pandangan penting beliau adalah matematika harus dihubungkan dengan realitas dan matematika sebagai aktivitas manusia (mathematics as human activities). Pertama, matematika harus dekat terhadap siswa dan harus dikaitkan dengan situasi kehidupan siswa seharihari. Kedua, matematika sebagai aktivitas manusia sehingga siswa harus diberi kesempatan untuk belajar melakukan 
aktivitas matematisasi pada semua topik dalam matematika dengan mengaitkan dan menghubungkan semua topik matematika. RME diadaptasi di Indonesia menjadi PMRI yang sesuai dengan konteks di Indonesia.

Menurut Freudenthal terdapat tiga prinsip kunci yang dapat dijadikan dasar dalam merancang pembelajaran. Prinsipprinsip PMRI adalah sebagai berikut: [4]

1. Guided reinvention and didactical phenomenology (Penemuan terbimbing melalui matematisasi)

Belajar matematika dalam PMRI adalah aktivitas manusia, maka penemuan terbimbing dapat diartikan bahwa siswa diberikan kesempatan seluas-luasnya untuk mengalami sendiri proses yang sama saat konsep matematika ditemukan.

Prinsip ini dapat diinspirasikan dengan menggunakan prosedur secara informal ke tingkat belajar matematika secara formal. Upaya ini akan tercapai jika pengajaran yang dilakukan menggunakan situasi yang berupa fenomena-fenomena yang mengandung konsep matematika dan nyata dengan kehidupan sehari-hari siswa.

\section{Progressive mathematization}

(Fenomena Mendidik)

Situasi yang berisikan fenomena yang dijadikan bahan dan area aplikasi dalam pengajaran matematika haruslah berangkat dari keadaan yang nyata terhadap siswa sebelum mencapai tingkat matematika secara formal. Upaya ini akan tercapai jika pengajaran yang dilakukan menggunakan situasi yang berupa fenomena-fenomena yang mengandung konsep Matematika dan nyata terhadap kehidupan sehari-hari siswa.

3. Self-developed models (Model-model siswa sendiri)

Peran self-developed models merupakan jembatan bagi siswa dari situasi real ke situasi konkrit atau dari informal matematika ke formal matematika. Artinya siswa membuat model sendiri dalam menyelesaikan masalah. Pertama adalah model suatu situasi yang dekat dengan alam siswa. Dengan generalisasi dan formalisasi model tersebut akan menjadi berubah menjadi model-of masalah tersebut. model-of akan bergeser menjadi model-for masalah yang sejenis. Pada akhirnya akan menjadi model dalam formal matematika.

\section{Karakteristik PMRI}

Seperti yang telah disampaikan di bagian depan PMRI itu realistik. Secara menyeluruh ciri-ciri PMRI itu menurut Treffers: [5]

1. The use of context (kontekstual)

Masalah kontekstual haruslah sebagai aplikasi dan sebagai titik tolak dari mana matematika yang diinginkan dapat muncul.

2. The use of model (menggunakan model) Menggunakan model, skema, dan simbolisasi yang menekankan penyelesaian secara informal sebelum menggunakan cara formal atau rumus dari pada hanya mentransfer rumus atau matematika formal secara langsung.

3. The use of student's own productions and contructions (menggunakan karya dan kontruksi diri) 
Kontribusi yang besar pada proses belajar mengajar diharapkan dari konstruksi siswa sendiri yang mengarahkan mereka dari metode unformal mereka ke arah yang lebih formal atau standar.

4. The interactive character of the teaching process (proses pembelajaran yang interaktif)

Negosiasi secara eksplisit, intervensi, kooperasi dan evaluasi sesama siswa dan guru adalah faktor penting dalam proses belajar secara konstruktif dimana strategi informal siswa digunakan sebagai jantung untuk mencapai yang formal.

5. The interwinement of various learning strands (adanya keterkaitan antara berbagai unit/topik)

Pendekatan holistik, menunjukkan bahwa unit-unit belajar tidak akan dapat dicapai secara terpisah tetapi keterkaitan dan keterintegrasian harus dieksploitasi dalam pemecahan masalah.

\section{Metode}

Berdasarkan judul dan rumusan masalah, penelitian yang penulis angkat adalah penelitian yang bersifat kualitatif tentang perkembangan PMRI di LPTKLPTK se-Bandung Raya. Metode yang digunakan dalam penelitian ini adalah metode penelitian kualitatif yang akan menghasilkan data deskriptif berupa katakata tertulis atau lisan dari subjek yang diamati. Penelitian ini termasuk penelitian deskriptif eksploratif, yang bertujuan untuk menggali informasi sebanyakbanyaknya kemudian menggambarkan keadaan dan mengungkapkan fakta yang ada dari informasi yang diperoleh dan selanjutnya menjelaskan secara deskriptif tentang fakta yang bersangkutan. Penelitian deskriptif dalam penelitian ini dimaksudkan agar dapat mengungkap atau memperoleh informasi dari data penelitian secara menyeluruh, luas, dan mendalam. [6]

Penelitian ini dilaksanakan di LPTKLPTK se-Bandung Raya. Adapun LPTK yang dimaksud yaitu LPTK yang merupakan mitra IP PMRI untuk mengembangkan PMRI yaitu UPI, serta LPTK yang pernah mengikuti pelatihan yaitu UNPAS, UNINUS, UNLA, dan STKIP Siliwangi.

Subjek penelitian ini adalah dosendosen yang merupakan Tim PMRI di LPTK UPI, serta UNPAS, UNINUS, UNLA, dan STKIP Siliwangi. Alasan memilih dosen-dosen yang merupakan Tim PMRI sebagai subjek penelitian adalah karena sebelumnya dosen-dosen yang bersangkutan sudah mengikuti beberapa kali workshop PMRI.

Teknik pengumpulan data yang digunakan adalah dengan menggunakan metode observasi, metode angket, metode wawancara, dan dokumentasi.

1. Angket

Angket dalam penelitian ini diberikan kepada semua subjek penelitian yaitu: dua dosen UPI, satu dosen UNPAS, dua dosen Uninus, satu dosen UNLA, dan tiga dosen STKIP Siliwangi. Angket ini diberikan untuk mengetahui perkembangan PMRI di LPTK, kegiatan yang sudah dilakukan unuk mengembangkan PMRI, serta kesulitan 
yang dihadapi untuk mengembangkan PMRI. Angket digunakan untuk melengkapi dan memperkuat data yang telah diperoleh dari instrumen lain. Angket dalam penelitian ini adalah angket tertutup, yaitu butir-butir angket yang disajikan sudah tersedia alternatif jawaban sehingga responder tinggal memilih jawaban yang sesuai.

2. Observasi

Observasi adalah suatu teknik yang dilakukan dengan cara mengadakan pengamatan secara teliti terhadap kegiatan yang sedang berlangsung. Observasi yang dilakukan dalam penelitian ini adalah melakukan pengamatan secara langsung ke sekolah yang dibina oleh LPTK dan pencatatan mengenai kegiatan yang sudah atau yang sedang dilakukan oleh LPTK seBandung Raya untuk mengembangkan PMRI.

3. Wawancara

Wawancara digunakan untuk mendapatkan informasi secara langsung dengan nara sumber yang terkait yaitu: dua dosen UPI, satu dosen UNPAS, dua dosen Uninus, satu dosen UNLA, dan tiga dosen STKIP Siliwangi. Wawancara digunakan untuk mengungkap perkembangan PMRI di LPTK, kegiatan yang sudah dilakukan unuk mengembangkan PMRI, kesulitan yang dihadapi untuk mengembangkan PMRI serta bantuan yang diperlukan oleh LPTK untuk mengembangkan dan menyebarluaskan PMRI. Wawancara dilakukan berdasarkan pedoman wawancara yang disusun.

\section{Dokumentasi}

Dokumentasi adalah cara memperoleh data dengan melihat dan meneliti dokumen atau catatan yang berupa foto atau tulisan, transkip, buku, surat kabar, majalah, notulen rapat, agenda, dan sebagainya. Dokumentasi digunakan untuk memperkuat data yang diperoleh dalam observasi, angket, dan wawancara.

\section{Hasil dan Pembahasan}

\section{A. Hasil Penelitian}

Seperti telah dinyatakan pada bab sebelumnya, tujuan utama dari penelitian ini adalah ingin mengungkap perkembangan PMRI di LPTK seBandung Raya.

Dalam penelitian ini informasi yang diperoleh berasal dari dokumentasi (majalah PMRI, Website, dan foto), angket, observasi (sekolah yang dibina oleh Tim PMRI UPI) dan wawancara yang dilakukan langsung oleh peneliti terhadap responden.

\section{Observasi}

Observasi yang dilakukan peneliti berupa pengamatan terhadap data-data yang dikeluarkan oleh PMRI Pusat yaitu majalah PMRI, melakukan observasi ke MIN Cicend yang merupakan sekolah binaan Tim PMRI di UP dan SMPN 12 Bandung pada tanggal 17 Mei 2013, serta mendatangi seminar dengan tema PMRI di UNINUS yang merupakan kelanjutan dari pelatihan yang telah diikuti oleh perwakilan dosen UNLA.

Observasi ke MIN Cicendo pada hari sabtu tanggal 6 April 2013. Observasi di kelas 5 dengan guru Bu Ana. 
Adapun jumlah kelas dan jumlah murid di MIN Ciendo adalah:

Tabel 1.

Sebaran Jumlah Siswa

\begin{tabular}{|lll|}
\hline Kelas & Jumlah Kelas & Jumlah Murid \\
\hline 1 & 2 & 68 \\
\hline 2 & 2 & 68 \\
\hline 3 & 1 & 49 \\
\hline 4 & 1 & 44 \\
\hline 5 & 2 & 62 \\
\hline 6 & 1 & 34 \\
\hline
\end{tabular}

Dari 6 kelas di MIN Cicendo yang telah ikut uji coba PMRI: Kelas 1 dengan 2 kelas berjumlah 68 murid sejak 2004, nama guru Neneng Yeti kemudian Kelas 1 dengan 1 kelas, 49 murid sejak 2004 dengan nama guru Euis Nurhayati. Di tahun 2005, Kelas 1 dengan 2 kelas berjumlah 68 murid dengan nama guru: nis Aisyah, Nani Rohaeni.

PMRI di mata guru MIN Cicendo merupakan pembelajaran yang menyenangkan, membangkitkan kreatifitas dan keaktifan siswa, hanya guru harus selalu ada persiapan yang matang, juga alat peraga yang diusahakan selalu ada meskipun alat peraga yang susah di dapat kadang menyulitkan guru juga. Partisipasi orang tua murid di MIN Cicendo kurang reponsif dalam pengadaan bahan ajar, mengingat taraf hidup 50\% kurang mampu, namun PMRI ini disambut baik. Setelah MIN Cicendo ini tidak dibantu dalam bentuk bantuan financial dan pertemuan dengan tim pengembangan LPTK dari LPTK tidak teratur dan tidak terjadwal maka MIN Cicendo mengalami kesulitan, adapun kesulitan yang didapat diantaranya yaitu sumber dana untuk menyiapkan bahan ajar dan media serta kekurangan sumber daya. 242
Selanjutnya peneliti mengikuti seminar Seminar Nasional Pendidikan Matematika 2013 pada Februari 2013 dengan tema: "Pembelajaran Matematika Realistik Indonesia sebagai Upaya Meningkatkan Kualitas Pembelajaran Matematika dan Upaya Menumbuhkan Karakter Bangsa" yang diadakan oleh UNINUS. Pembicara Utama yaitu Dr. RK Sembiring (Ketua Pendidikan Matematika Realistik Indonesia), Prof. Dr. Darhim, M.Si. (Dosen jurusan Pendidikan Matematika UPI, Staf ahli Ditjen PMPTK Kemendiknas, konsultan bermutu kerjasama Bank dunia-Pemerintah Belanda_kemendiknas, Tim Uji coba PMRI), dan Dr. Ahmad Mudrikah Drs, MPd (Dosen Program Studi Pendidikan Matematika Uninus). Pada kegiatan seminar, peneliti menanyakan mengenai perkembangan PMRI di Bandung kemudian Dr. RK Sembiring menyatakan bahwa "Perkembangan PMRI di Bandung sangat memprihatinkan dan alasannya tidak tahu". Namun berbeda pendapat dengan Prof. Dr. Darhim, M.Si. “ Menurut saya berkembang meskipun tidak cepat, hal ini terbukti dengan banyaknya hasil penelitian di UPI yang meneliti mengenai PMRI, selain itu mata kuliah PMRI pernah menjadi mata kuliah tersendiri di S2 namun sekarang ada di S3 saja PMRI menjadi mata kuliah tersendiri".

2. Angket

Angket dalam penelitian ini diberikan kepada semua subjek penelitian yaitu: dua dosen UPI, satu dosen UNPAS, dua dosen Uninus, satu dosen UNLA, dan tiga dosen STKIP Siliwangi. Angket ini diberikan untuk mengetahui perkembangan PMRI di 
LPTK, kegiatan yang sudah dilakukan unuk mengembangkan PMRI, serta kesulitan yang dihadapi untuk mengembangkan PMRI. Angket mengungkap tiga kriteria yaitu mengenai PMRI $(1,3,7,11,14,16,19,20)$, kegiatan yang sudah dilakukan oleh LPTK untuk mengembangkan PMRI $(2,4,6,8,9,10$, $12,13,15,18)$, serta kesulitan yang dihadapi oleh LPTK $(5,17)$. Secara umum, respons terhadap setiap item pernyataan menunjukkan hal yang positif.

3. Dokumentasi

Data didapati melalui web resmi PMRI, web resmi PMRI UPI, serta web resmi PMRI LPTK se-Indonesia.

\section{Wawancara}

Teknik wawancara dalam penelitian ini digunakan untuk melengkapi data, wawancara ditujukan bagi semua responden yang digunakan sebagai cros cek data lainnya yang telah dilakukan oleh peneliti. Pelaksanaan wawancara ini dibatasi oleh kisi-kisi yang telah disiapkan oleh peneliti yang disesuaikan. Hasil wawancara secara keseluruhan dicatat oleh peneliti dalam transkrip hasil wawancara yang terdapat dalam lampiran.

\section{B. Pembahasan}

Setelah dilakukan analisis terhadap data hasil penelitian, maka selanjutnya akan dibahas mengenai hasil dan temuan penelitian. Pembahasan ini akan difokuskan pada permasalahan yang ada pada Bab I.

\section{UPI}

Perkembangan PMRI di UPI dimulai sebelum tahun 2000. Sebelum tahun 2000, tokoh-tokoh PMR Belanda menawarkan bantuan melalui sebuah proyek dalam
PMR ke ITB. Oleh ITB diterima. Kemudian melalui Dirjen Dikti beberapa orang LPTK dimintakan untuk membantu. Orang-orang LPTK yang diminta untuk membantu itu ialah Prof. Drs. R. Soejadi dari UNESA Surabaya, DR. J. Marpaung dari USD, Prof. DR. Suryanto dari UNY, dan Prof. H. E. T. Ruseffendi, PhD dari UPI.

Ujicoba PMRI di sekolah secara formal termasuk bagian dari proyek PMRI yang dibiayai Ditjen Dikti. Percobaan pertama di sekolah dimulai awal tahun 2000 di 3 SD (SD PN Sabang Bandung dan SD PN Setiabudi), dan termasuk 1 MIN (MIN Cicendo) atas permintaan Dept. Agama, sekarang sudah tersebar banyak sekolah.

\section{UNPAS}

Perkembangan PMRI di UNPAS dimulai pada tahun 2000. Seperti perkembangan PMRI di UPI, UNPAS juga dijuntuk sebagai LPTK untuk mengembangkan PMRI di Jawa Barat khususnya di Bandung. Dalam mengsosialisasikan PMRI ini UNPAS belum maksimal dalam menyebarluaskan pembelajaran ini dikarenakan kurangnya dukungan dari pemerintah dan juga pendanaan yang belum ada untuk mengembangkan PMRI.

Dalam hal ini, perkembangan PMRI masih belum berkembang secara baik dan menyeluruh. Bahkan sebenarnya banyak guru yang belum mengetahui tentang PMRI. Di UNPAS sendiri PMRI tergolong masih asing, hal ini terlihat hanya kurang dari 10 karya tentang PMRI dalam 5 tahun terakhir. 


\section{UNLA}

Perkembangan PMRI di UNLA dikenal pada tahun 2000an dan mengenal PMRI dari media elektronik. PMRI di UNLA diterapkan tidak hanya dalam perkuliahan, tepapi dalam PPL dan PPM juga sudah mulai diperkenalkan baik kepada mahasiswa ataupun masyarakat.

PMRI di UNLA sudah mulai dikembangkan mulai dari mahasiswa untuk mensosialisasikan kepada sekolahsekolah sehingga mulai dienal dalam masyarakat luas. Hanya saja, dalam menyebarluaskan PMRI masih banyak dosen yang belum mengetahui secara detail tentang PMRI sehingga hanya beberapa dosen yang memperkenalkan PMRI kepada mahasiswa. Hasilnya mahasiswa belum banyak mengetahui tentang PMRI itu sendiri.

\section{UNINUS}

Dalam perkembangan PMRI di UNINUS dilakukan dengan beberapa cara diantaranya dengan seminar, penelitian, dan juga dimasukkan dalam perkuliahan SBM. PMRI di UNLA dikenal pada sekitar tahun 2000 dan mulai disebarluaskan dengan banyaknya pelatihan dan seminar yang dilakukan oleh UNINUS.

Dalam sosialisasi PMRI yang dilakukan oleh UNINUS hanya sebatas seminar saja. Oleh karena itu, dalam perkembangannya belum begitu maksimal.

\section{STKIP Siliwangi}

Perkembangan PMRI di STKIP Siliwangi dikenal pada tahun 2004, dan dilanjutkan dengan mengikuti workshop pada tahun 2012. Perkembangan PMRI di STKIP Siliwangi mulai berkembang dengan adanya penelitian dosen muda yang bertema PMRI dan banyak mahasiswa yang melakukan penelitian yang bertemakan PMRI. Dalam kenyataannya perkembangan PMRI ini kurang merata, hal ini bisa dilihat hanya beberapa dosen yang mengetahui tentang PMRI. Sedangkan sudah cukup banyak mahasiswa yang skripsinya bertemakan PMRI.

Pada saat ini STKIP mencoba untuk mengembangkan PMRI dengan salah satu caranya adalah penelitian dosen muda bertema PMRI. STKIP Siliwangi mencoba untuk menjadi pelopor dan pusat PMRI di Jawa Barat khususnya Bandung Raya. Perkembangan PMRI di Indonesia pertama kali yaitu adanya tawaran bantuan dari Belanda. Sekarang ini karena tidak ada lagi bantuan dari Belanda maka dalam perkembangannya tidak segencar dahulu.

\section{Penutup}

1. Perkembangan PMRI di Jawa Barat khususnya Bandung Barat belum berkembang maksimal sesuai yang diharapkan pada saat pertama kali PMRI dikenalkan di Indonesia. Hal ini dapat dilihat hanya beberapa yang menerapkan PMRI itu sendiri di sekolah. Pada saat sekarang ini LPTKLPTK sudah mulai jarang mengadakan pelatihan/workshop, seminar dan juga penelitian yang bertemakan PMRI. Kemudian ditunjang juga bahwa kurang adanya dukungan dari pemerintah mengenai PMRI. Sehingga, PMRI dalam perkembangannya belum menyebar secara menyeluruh di Bandung Raya. 
2. Sejak tahun 2000 hingga sekarang, walaupun sekarang sudah mulai jarang banyak yang telah dilakukan dalam mengembangkan dan menyebarluaskan PMRI diantaranya adalah seminar, pelatihan bagi guru dan mahasiswa, workshop, dan penelitian yang dilakukan oleh setiap LPTK.

3. Dalam mengembangkan dan menyebarluaskan PMRI terdapat beberapa kesukaran diantaranya adalah: 1). Kebijakan/ sistem pemerintah yang kurang mendukung; 2). Pendanaan yang diperlukan dalam mengembangkan PMRI; 3). Terbatasnya narasumber dan pakar PMRI yang terdapat di Bandung; 4). Dalam pelaksanaannya tidak efisien dalam waktu dan juga tenaga.

4. Bantuan yang diperlukan dalam mengembangkan PMRI diantaranya 1). Bantuan dana riset PMRI untuk guru dan dosen; 2). Sumber bahan ajar/ buku panduan untuk guru dan siswa tentang PMRI; 3). Pelatihan PMRI; 4). Workshop yang berkelanjutan; 5). Dukungan dari pemerintah dalam mengembangkan PMRI.

\section{DAFTAR PUstaka}

[1] E. T. Ruseffendi, Dasar-dasar Matematika Modern untuk Guru, Bandung: Tarsito, 1984.

[2] U. Sumarmo, (2012, Desember), Pembelajaran Keterampilan Membaca Matematika Pada Siswa Sekolah Menengah, math.sps.upi.edu/?p=64.

[3] S. Hadi, Pendidikan Matematika Realistik, Banjarmasin: Tulip, 2005.
[4] S. Ahyan, (2012, Desember), Sekilas tentang PMRI, http://shahibul1628.wordpress.com/int roduction-to-rme/sekilas-tentangpmri/

[5] E. T. Ruseffendi, 2006.

[6] Sugiyono, Metode Penelitian, Cetakan Kedua belas, Bandung: Alfabeta, 2008. 

e-mosharafa.org

This page is intentionally left blank 